\title{
Chapter 4 \\ The Fossil Record of Biodiversity \\ in Angola Through Time: A Paleontological \\ Perspective
}

\author{
Octávio Mateus, Pedro M. Callapez, Michael J. Polcyn, Anne S. Schulp, \\ António Olímpio Gonçalves, and Louis L. Jacobs
}

\begin{abstract}
This chapter provides an overview of the alpha paleobiodiversity of Angola based on the available fossil record that is limited to the sedimentary rocks, ranging in age from Precambrian to the present. The geological period with the highest paleobiodiversity in the Angolan fossil record is the Cretaceous, with more than $80 \%$ of the total known fossil taxa, especially marine molluscs, including ammonites as a majority among them. The vertebrates represent about $15 \%$ of the known fauna and about one tenth of them are species firstly described based on specimens from Angola.
\end{abstract}

O. Mateus $(\square)$

GeoBioTec, Faculdade de Ciências e Tecnologia, Universidade Nova de Lisboa,

Lisbon, Portugal

Museu da Lourinhã, Rua João Luis de Moura, Lourinhã, Portugal

e-mail: omateus@fct.unl.pt

P. M. Callapez

CITEUC; Departamento de Ciências da Terra, Faculdade de Ciências e Tecnologia,

Universidade de Coimbra, Coimbra, Portugal

e-mail: callapez@dct.uc.pt; jacobs@smu.edu

M. J. Polcyn · L. L. Jacobs

Roy M. Huffington Department of Earth Sciences, Southern Methodist University,

Dallas, TX, USA

e-mail: mpolcyn@smu.edu
A. S. Schulp
Naturalis Biodiversity Center, Leiden, The Netherlands
Faculty of Earth and Life Sciences, VU University Amsterdam, Amsterdam, The Netherlands e-mail: anne.schulp@naturalis.nl

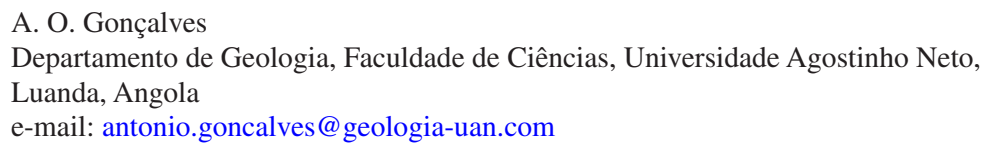

A. O. Gonçalves

Departamento de Geologia, Faculdade de Ciências, Universidade Agostinho Neto,

Luanda, Angola

e-mail: antonio.goncalves@geologia-uan.com 
Keywords Ammonites · Benguela Basin - Cenozoic · Cretaceous · Cuanza Basin · Dinosaur · Invertebrates · Mammals · Mollusca · Mosasaur · Namibe Basin · Paleobiodiversity $\cdot$ Pleistocene $\cdot$ Vertebrate $\cdot$ Plesiosaur $\cdot$ Turtle

\section{Studies of Paleobiodiversity}

The study of paleobiodiversity, i.e., the development of biodiversity through geological time, is challenging at multiple levels. In addition to the issues and biases affecting the study of the diversity of modern life, understanding paleobiodiversity faces extra challenges, mostly because of the dependency on the fossil record. Glimpses of entire ecosystems and clades may never reach the paleontologist's eyes if appropriate rocks of that exact time and space were not formed, or if formed, did not preserve fossils, or are eroded away or otherwise inaccessible (see Jackson and Johnson 2001; Crampton et al. 2003).

The study of life's diversity in the past is filtered by the remains that can leave traces and fossilize, remains that actually fossilized, fossils existing today, fossils accessible today, fossils collected (number of fossils accessible to scientists), and species recognised (Fig. 4.1). Moreover, the definition and discrimination of species in the fossil record can be problematic.

Angola has no known fossiliferous rocks from the Paleozoic (541-251 Ma-millions of years ago) nor the Jurassic (199-145 Ma) leaving only windows to life in the territory during the Triassic (251-199 Ma), Cretaceous (145-66 Ma), and Cenozoic (66 Ma -Present) (Fig. 4.2). The chances of finding Paleozoic or Jurassic fossils from Angola are essentially zero. Thus, within the last $550 \mathrm{Ma}$, the known

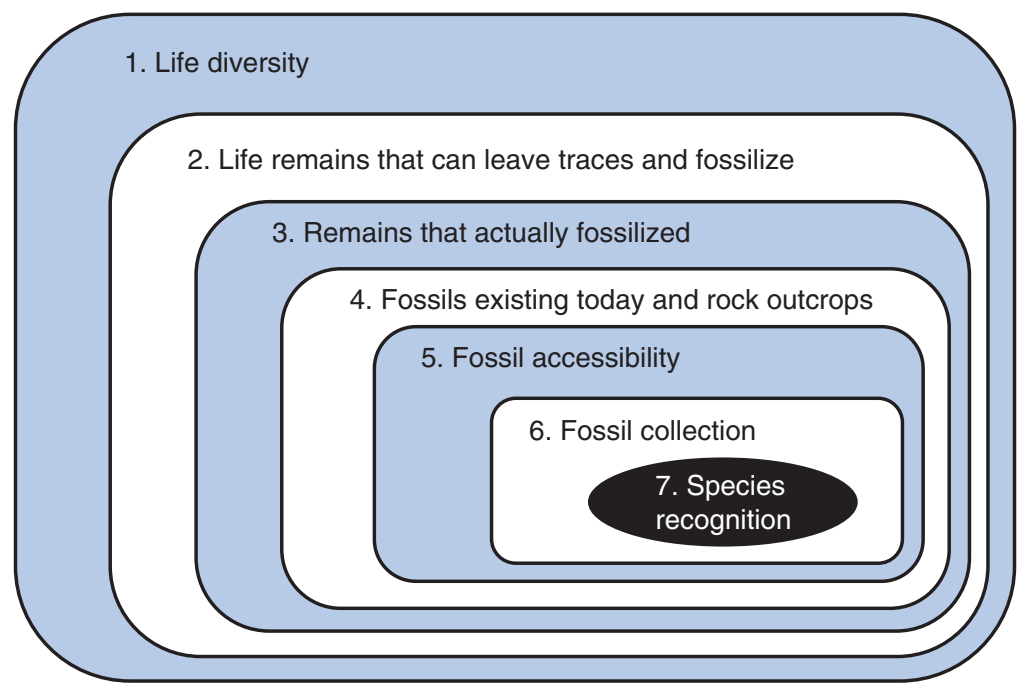

Fig. 4.1 The seven layers of filters of uneven preservation in the fossil record that obscure accurate reconstruction of paleobiodiversity 

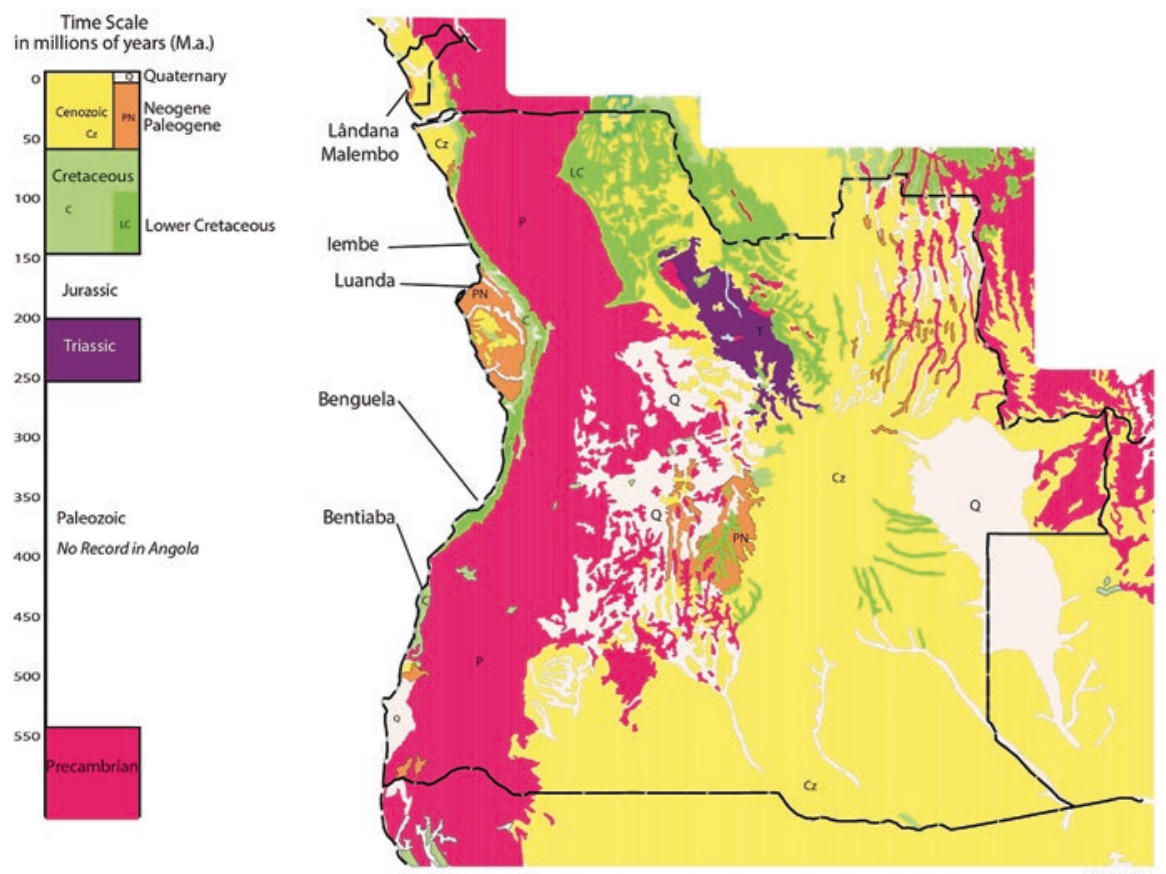

Fig. 4.2 The geological record of Angola, in a stratigraphic log (left) and geological map (right), leaves more than $350 \mathrm{Ma}$ of blank geological record. Map extracted after Africa Geological Map 1:30.000.000 by U.S. Geological Survey, 2002 available at www.uni-koeln.de/sfb389/e/e1

rocks of Angola represent less than 196 million years of geologic time, leaving more than 354 million years (64\% of the time) with no known fossil record.

Despite the incompleteness of the fossil record and consequent limitations to the study of the paleobiodiversity, cooperative research and modern databases can, however, improve approximation of the estimated number of species in the fossil record. The PaleoBiology Database (paleobiodb.org) is, by far, the most comprehensive database of fossils, which, together with the scientific literature and our own research, contributed to the Supplementary Material and its summary in Table 4.1 that compiles the list of the fossil taxa in Angola, with updated taxonomy, geological age, locality, and references. The fossil record can be used as a lower limit for the alpha paleobiodiversity for specific times and locations in Angola, although it is likely an underestimate of true paleodiversity in the vast majority of cases. The total of all fossil species is a gross underestimation of paleodiversity for the full extent of the time involved, exacerbated by missing intervals of fossiliferous rocks. However, the pattern through time can inform an understanding of general trends.

Fossil collecting in Angola has been conducted since the nineteenth century with Friederich Welwitsch, José de Anchieta (1885), Freire de Andrade, Augusto Eduardo Neuparth and others (Brandão 2008, 2010; Silva and Geirinhas 2010; Callapez et al. 2011; Masse and Laurent 2016). Numerous paleontologists have contributed to the 


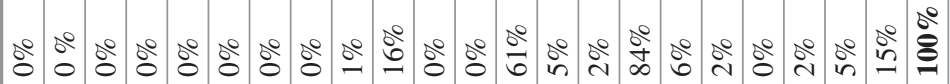
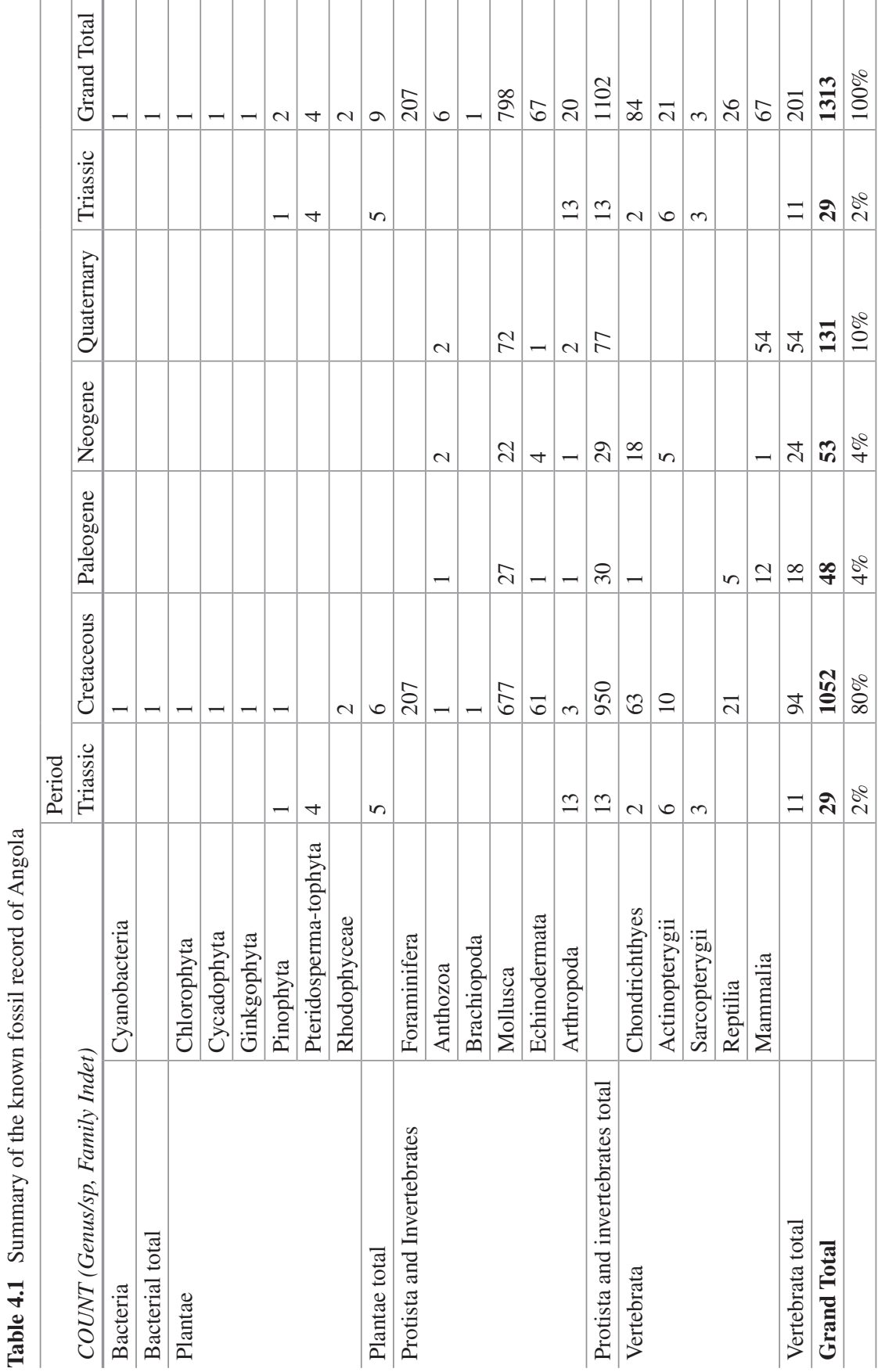
understanding the paleobiodiversity of Angola, since the first explorations and studies: Fernando Mouta, Paul Choffat, Carlos Teixeira, Carlos Freire de Andrade, Edgard Casier, A Jamotte, M Leriche, Heitor de Carvalho, E Dartevelle, Miguel Telles Antunes, Alexandre Borges, Philippe Brebion, Gaspar Soares de Carvalho, Louis Dollo, Henri Douvillé, Otto Haas, Manuel Mascarenhas Neto, Arménio Tavares da Rocha, Gumerzindo Henriques da Silva, LF Spath, António Ferreira Soares, Maurice Collignon, among many others (see bibliography compiled by Nunes 1991). In vertebrate paleontology the work of Miguel Telles Antunes and co-authors is noteworthy. Today, various researchers work on the paleontology of Angola, among them is the team of the Projecto PaleoAngola (paleolabs.org/paleoangola), with regular yearly scientific expeditions since 2005 (Jacobs et al. 2006, 2016).

\section{A Brief Geological History and Context of Angola}

The most significant geological event governing the paleogeography of Angola is the opening of the South Atlantic Ocean, in which Africa and South America rifted apart beginning in the Early Cretaceous Epoch about 134 million years ago and the subsequent drifting apart of these continents as the South Atlantic grew (Guiraud and Maurin 1991; Buta-Neto et al. 2006; Quirk et al. 2013; Pérez-Díaz and Eagles 2017). After about 120 million years ago, marine deposition along the coast began to preserve fossils. Africa's place in Gondwana prior to this time resulted in the lack of a marine record for the entire Paleozoic Era and the consequent lack of a fossil record for that time.

As the South Atlantic opened it was colonised by species moving in from the southern ocean and, as a connection between the North Atlantic and South Atlantic oceans developed, from the north. Sea turtles (Angolachelys mbaxi) and mosasaurs (Angolasaurus bocagei and Tylosaurus iembeensis), with relatives to the north, first occur at about 88 million years ago. Along with them were plesiosaurs, probably with southern affinities. Washed into the sea and found with marine creatures, is the sauropod dinosaur Angolatitan adamastor, which is probably a remnant of a more broadly distributed Gondwanan dinosaur assemblage. At that time, coastal Angola lay approximately 10-12 degrees further south than today.

Geologic uplift along the coast resulted in the erosion of rock and loss of the fossil record from effected strata. Permian and Jurassic uplift eliminated those intervals from the terrestrial fossil record. Early and Late Cretaceous uplift also occurred, prior to burial of the remaining Cretaceous with up to $1.5-2 \mathrm{~km}$ of sediments, since removed by erosion accompanying mid-Cenozoic uplift beginning around $30 \mathrm{Ma}$ and $20 \mathrm{Ma}$ (Green and Machado 2015). Uplift from as young as 45,000 years ago also has been recorded along the Angolan coast (Walker et al. 2016), resulting in a large diversity of fossiliferous raised-beach deposits, frequently associated with pre-historic shell-middens with Paleolithic industries. 


\section{The Precambrian - The First Fossils}

Precambrian Era (geologic time since the formation of Earth and prior to $541 \mathrm{Ma}$ ) rocks worldwide are mostly devoid of fossils as life was unicellular for most time and only macroscopic in the last stages. The shale-limestone series of the Bembe System in Angola includes dolomitic limestones, mostly devoid of fossils, but containing levels with concentrations of coalescent stromatolites (structures due to cyanophilic activity) attributable to the genera Collenia and Conophyton in Mavoio, Alto Zambeze, and Humpata (Vasconcelos 1951; Antunes 1970; Duarte et al. 2014).

In Angola, no fossils are known from the Paleozoic (Cambrian through Permian periods), which represents a time gap of more than 290 million years (Fig. 4.2).

\section{The Triassic - Inner Basins}

The Triassic is a geological period stretching from about 250 to $200 \mathrm{Ma}$. The beginning and end of this interval are both marked by mass extinction events, the older Permian-Triassic extinction event, concomitant with the Siberian Magmatic event, marking the initiation of the Triassic Period. The vast supercontinent Pangea existed until the Triassic, after which it gradually began to break-up apart, separating the two masses of land, Laurasia to the north and Gondwana to the south. The global climate during the Triassic Period was warm and dry, with deserts covering much of the interior of Pangea. The end of the Triassic was marked by another major mass extinction related with the Central Atlantic Magmatic Province and the early opening of the North Atlantic. Therapsids (a large group containing mammals and their extinct relatives) and archosaurs (dinosaurs, birds, crocodiles and their relatives) were the major terrestrial vertebrates during this time. The dinosaurs first appeared in the Triassic. The first true mammals, which are derived therapsids, evolved during this period, as well as the first flying vertebrates, the pterosaurs.

Triassic outcrops of Angola are restricted to the Baixa de Cassange (Cassange Depression) in Malanje and Lunda-Norte in rocks referred to the Karoo Supergroup geological unit.

\section{Plants and Invertebrates}

The Triassic paleoflora of Angola includes the extinct genera Glossopteris, Sphenopteris, and Noeggerathiopsis (Teixeira 1948a, 1961). A few fossils indicate a freshwater environment and a Triassic age. These include the coleopteran Coptoclavidae insect Coptoclavia africana and 12 conchostracan crustaceans: Estheriella moutai Leriche 1932, E. cassambensis Teixeira 1958, Estheria anchietai Teixeira 1947, E. (Echinestheria) marimbensis Marliére 1950, E. (Euestheria) mangaliensis Jones 1862, Palaeolimnadiopsis reali Teixeira 1958, Palaeolimnadia 
(Palaeolimnadia) wianamattensis (Mitchell), P. (Grandilimnadia) oesterleni Tasch 1987, P. (G.) africania Tasch 1987, Gabonestheria gabonensis (Marliére 1950), Cornia angolata Tasch 1987, and Estheriina (Nudusia) cf. rewanensis Tasch 1979.

\section{Vertebrates}

The only Triassic vertebrates known from Angola are fishes, including the Elasmobranchii Lissodus cassangensis, the paleoniscoids Perleidus lutoensis Teixeira 1947, Palaeonisciformes canobiid Marquesia moutai, Halecostomi Angolaichthys lerichei Teixeira, the ray-finned Teffichthys lehmani and T. lutoensis, and the Sarcopterygii lungfish Microceratodus angolensis.

This faunal assemblage indicates a freshwater environment with insects and a nearly exclusively endemic fauna. Based on the fishes, a Lower Triassic age (252$247 \mathrm{Ma}$ ) is indicated for Lunda and Baixa de Cassange rocks (Murray 2000; Antunes et al. 1990). No tetrapods have been collected so far.

\section{The Early Cretaceous - The Opening of South Atlantic}

Most of the fossils and outcrops of Cretaceous age in Angola are in MesozoicCenozoic basins of coastal Angola: the Cabinda, Zaire, Cuanza, Benguela, and Namibe sedimentary basins (Antunes 1964; Séranne and Anka 2005; Guiraud et al. 2010), bordered by basement rocks. Almost all formations are mostly marine except for the ichnofauna from the Catoca mine (Marzola et al. 2014; Mateus et al. 2017), in Lunda-Sul. The oldest fossiliferous Cretaceous formations seen in outcrop seem to be Barremian to Aptian lacustrine deposits that contain unidentified gastropods (Ceraldi and Green 2016).

\section{Plants, Protists and Invertebrates}

Cretaceous plant remains in Angola seem to be rare (see Supplementary Material), but several examples of unstudied field contexts with transitional facies, namely above the Cuvo units, might come to reveal new fossil sites. The same situation is likely for palynomorphs and dinoflagellates of Early Cretaceous and more recent ages. Plants are known from pollen taxa such as Classopolis sp. and Eucommiidites sp. Pachypteris montenegroi Teixeira 1948 is a Ginkgophyta Umkomasiaceae from Early Albian lagoonal sediments of the Cuanza Basin (Teixeira 1948b; Antunes 1964; Neto 1970; Nunes 1991) and first found in Angola. One species of Chlorophyta, one Cycadophyta, one Rhodophyceae, one Ginkgophyta, and two Pinophyta have been reported from Cabinda, Benguela and Cuanza Basin (Antunes 1964; Neto 1970; Nunes 1991; Araújo and Guimarães 1992; Tavares 2006). 
More than 200 foraminifera taxa were identified in the Cretaceous of Angola, and many indicate an Albian age, such as Globotruncana ventricosa (Rocha 1984; Antunes and Cappetta 2002; Antunes 1964; Jacobs et al. 2006).

Crustaceans are known from the Decapoda Parapirimela angolensis Van Straelen 1937 from the Albian of Iela beach, Benguela Basin (Ferreira 1957; Van Straelen 1937; Antunes 1964) and the ostracods Chloridella angolia and Petrobrasia tenuistriata longinsuela from Quiçama, Cuanza Basin, (Berry 1939; Antunes 1964) and Cabinda (Araújo and Guimarães 1992), respectively.

The Early Cretaceous of Angola yielded fossils of seven species of Scleractinean corals, one of brachiopod and eight crustaceans.

Of the more than known 600 species of molluscs from the Cretaceous of Angola, the vast majority are ammonites, many are unique to Angola and received related specific epithets such as the Anisoceras teixeirai, Durnovarites autunesi Collignon 1978, Durnovarites netoi, Elobiceras lobitoense Spath 1922, Hamitoides angolanus (Tavares 2006), followed by bivalves such as Neithea angoliensis Newton 1917, and gastropods such as "Cerithium" monteroi Choffat. By far, the ammonites are the most relevant portion of the Cretaceous biodiversity of Angola (Tavares et al. 2007; Haas 1942, 1943) and also age-indicators for geologists and paleontologists. Haas (1942) described and reported many ammonites from the Albian, some as new species including Hysteroceras falcicostatum Haas 1942 and H. intermedium Haas 1942. See the Supplementary Material for the complete list.

Echinoderms, mostly echinoids, are remarkably common in the Early Cretaceous of Angola, with about 50 taxa known, but that number depends on the validity and synonymisation of the taxa addressed (see the Supplementary Material for the complete list). A few echinoderms received names after Angolan toponyms and researchers such as the Douvillaster benguellensis Loriol 1888 and D. carvalhoi Loriol 1888 and Epiaster catumbelensis Loriol 1888, and Holaster domboensis Loriol 1888 from the Lower Cretaceous of Dombe Grande, Catumbela and Praia da Hanha (Loriol 1888; Ferré and Granier 2001; Tavares 2006; Tavares et al. 2007).

\section{Vertebrates}

In the Catoca Diamond Mine, in Lunda-Sul Province, mammaliamorph, crocodylomorph, and sauropod tracks were discovered in Early Cretaceous crater lake sediments. One sauropod track has skin impressions preserved. These are the only fossil vertebrate tracks known in Angola. The most surprising feature is the unexpectedly large size of the mammaliamorph footprints considering the age (Mateus et al. 2017). The Catoca Diamond Mine has an eruption age of around $118 \mathrm{Ma}$ (Aptian; Robles-Cruz et al. 2012). A fragment of a caudal vertebra of a sauropod dinosaur was recovered from Tzimbio, in northern Namibe, from strata that are likely Albian in age. 


\section{The Late Cretaceous - Marine Reptiles Flourish}

The Late Cretaceous is the time of the Cretaceous Period between 100.5 Ma and 66 million years ago. It is subdivided into the Cenomanian, Turonian, Coniacian, Santonian, Campanian and Maastrichtian ages, from the oldest to the most recent. The climate was warmer than present, although with a cooling trend throughout the period. In the oceans, where the sea-level was much higher than today, mosasaurs (a group of marine lizards) suddenly appeared and underwent a spectacular evolutionary radiation (Polcyn et al. 2014). Modern grade sharks also appeared and plesiosaurs diversified. These predators fed on the numerous teleost fishes, which in turn evolved into new advanced and modern forms (Neoteleostei). Ichthyosaurs and pliosaurs (a group of short-necked plesiosaurs), on the other hand, became extinct during the Cenomanian-Turonian anoxic event (Schlanger et al. 1987) and are not known from Angola. The end of Cretaceous is marked by the mass extinction of some three-quarters of plant and animal species on Earth, known as the CretaceousPaleogene (K/Pg) event (Archibald et al. 2010).

\section{Protists and Invertebrates}

The Late Cretaceous Foraminifera of Angola were studied by various researchers including Ferreira and Rocha (1957), Lapão and Simões (1972), Rocha (1984) and Blake et al. (1996) who list more than 180 taxa. Foraminifera are known from 15 taxa of Granuloreticulosea, such as the Gavelinellidae Anomalia berthelini from the Aptian to Cenomanian of Cabinda, Cuanza and Benguela Basins (Araújo and Guimarães 1992; Rocha 1984).

Molluscs of the Late Cretaceous count more than 240 known taxa, mostly ammonites (see Supplementary Material for the full list). Some were named after Angolan toponyms or after paleontologists that worked in Angola (Borges 1946; Carvalho 1961; Haas 1943; Howarth 1965; Cooper 1972, 1982; Cooper and Kennedy 1979): Acera choffati Rennie 1945, Axonoceras angolanum Haas 1943, Didymoceras cf. angolaense Haughton 1924 (Howarth 1965), Eutrephoceras egitoense Miller and Carpenter 1956, Kitchinites angolaensis Howarth 1965, Libycoceras dandense Howarth 1965, Lucina egitoensis Rennie 1945, L. angolensis Rennie 1929, Mammites mocamedensis Howarth 1966, Nostoceras mariatheresianum Haas 1943, Oiophyllites angolaensis Spath 1953, Prionocyclus carvalhoi Howarth 1966, Protacanthoceras angolaense Spath 1931, Prohysteroceras hanhaense (Haas 1942), P. angolaense (Boule et al. 1907), Protocardia moutai Rennie 1945, Pseudocalycoceras angolaense (Spath 1931), Pseudomelania salenasensis Rennie, Pterotrigonia borgesi Rennie 1945, Mortoniceras (Angolaites) stolikzcai (Spath 1922), Mortoniceras (?) rochai Collignon 1978, M. (Deiradoceras) reali Collignon 1978, Collignoniceras (Selwynoceras) reali Collignon 1978, and Solenoceras 
bembense Haas 1943. The ammonites are found in almost all Upper Cretaceous sections, including those of the Quissonde Formation from the beaches of Quimbala, Chamure, Cabeça da Baleia, Egito in Benguela Basin, Teba, Bembe in Cuanza Basin, Bentiaba and Salinas in Namibe, and Iembe in Bengo Province (Segundo et al. 2014).

Rennie (1945) describes ten species of gastropods and bivalves from Cabeça da Baleia, Egito-Praia: Trigonia (Scabrotrigonia) borgesi, Lucina egitoensis, Protocardia moutai, Pseudomelania egitoensis, Confusiscala angolensis, Acirsa (Plesioacirsa?) egitoensis, Dicroloma (Perissoptera) o'donnelli, Paleopsephaea o'donnelli, Acera choffati, and Ringicula moutai (Lapão and Pereira 1971).

More than ten echinoderm taxa are known from the Late Cretaceous of Angola, mostly echinoids, some received Angola-related names, such as the Toxasteridae Epiaster angolensis Haughton 1924, collected $150 \mathrm{~m}$ below the Itombe Formation at Zenza do Itombe, and E. carvalhoi Dartevelle 1953 (Haughton 1924; Kier and Lawson 1978; Néraudeau and Mathey 2000), Leiostomaster angolanus Greyling and Cooper 1995, Palaeostomatidae and Tholaster carvalhoi Greyling and Cooper 1995, and Holasteridae from the Middle Campanian of Egito Praia, near Quimbala.

\section{Vertebrates}

In Angola, a peak of vertebrate paleobiodiversity is observed in the Late Cretaceous, with more than 100 taxa recognised (Antunes 1964; Antunes and Cappetta 2002; Jacobs et al. 2006, 2009, 2016). This peak is in comparison with other time intervals and is likely an artifact of the inadequacies of the fossil record rather than a statement of biological reality. Most known Late Cretaceous sedimentary rocks from Angola are marine, thus the fossil assemblage also reflects this ecosystem. Nonmarine organisms are occasionally drifted into a marine setting, including the sauropod dinosaur Angolatitan adamastor Mateus et al. (2011) from Iembe, in Bengo Province, originally considered Turonian in age but following the discovery of the ammonite Protexanites sp. at Iembe, it is now considered Coniacian. Pterosaurs are known from the Maastrichtian marine sediments of Bentiaba, in Namibe Province. Angolatitan adamastor is the first dinosaur found in Angola. Its generic name means 'Titan of Angola' and the specific name refers to Adamastor made famous by Luís de Camões in the Lusíadas. It was $13 \mathrm{~m}$ long and lived in an arid environment (Mateus et al. 2011). A number of bones of large flying reptiles, pterosaurs, collected in the marine sediments of the Maastrichtian of Bentiaba are the only know pterosaur remains in sub-saharian Africa for this stage.

The fossil record of chondrichthyans shows a peak in Late Cretaceous deposits with 64 species known, including taxa only known in Angola or with Angolan toponyms such as Angolabatis angolensis, A. benguelaensis, Chlamydoselachus gracilis, Cretascymnus quimbalaensis, and Echinorhinus lapaoi named by Antunes and Cappetta (2002). The diversity of chondrichthyans includes representatives of most of the Cretaceous lineages: Hexanchiformes, Squaliformes, Rajiformes, Orectolobiformes, Odontaspidida, Lamniformes, Carcharhiniformes, and Squaliformes (Antunes and Cappetta 2002). 
In contrast to the diversity of chondrichthyans, the Late Cretaceous bony rayfinned fish from Angola are represented by ten taxa only, most likely due to the difficulty of identification of isolated remains, in comparison with the abundance of shark and ray teeth. The teleost genus Enchodus is known from various species (Enchodus bursauxi, E. crenulatus, E. elegans, E. faujasi and E. libycus). Other teleosts include Eodiaphyodus lerichei, Pseudoegertonia bebianoi, and Stephanodus libycus from the Late Campanian and Maastrichtian in Benguela and Namibe provinces (Antunes and Cappetta 2002) (Fig. 4.3).

Two Upper Cretaceous fossil localities from Angola are remarkably rich in large reptiles: Iembe in Bengo Province (Fig. 4.4) of Coniacian age ( 88 Ma), and Bentiaba in Namibe (Maastrichtian). The Coniacian provided the bizarre durophagous cryptodiran turtle Angolachelys mbaxi Mateus et al. (2009) that justified the erection of its own clade Angolachelonia, and the sauropod dinosaur Angolatitan adamastor. Indeterminate plesiosaur remains have also been recovered from this region. Mosasaurs are represented by Angolasaurus bocagei (Fig. 4.3), Tylosaurus iembeensis Antunes (1964) and an indeterminate halisaurine.

The richest vertebrate locality in Angola is near Bentiaba in Namibe province (Strganac et al. 2014, 2015a, b). The reptile list includes the cheloniid turtles Euclastes sp., Protostega sp. and Toxochelys sp. Terrestrial reptiles include isolated remains that allow undetermined large pterosaurs, an undetermined sauropod based on a metapodial, and a possible hadrosaur based on an isolated phalanx (Mateus et al. 2012). The squamate mosasaurs are, by far, the most abundant and speciose group of tetrapods, and include Globidens phosphaticus, Prognathodon kianda, Halisaurus sp., Mosasaurus sp., Phosphorosaurus sp., and 'Platecarpus' ptychodon (Polcyn et al. 2007, 2010, 2014; Schulp et al. 2006, 2008, 2013). The plesiosaur

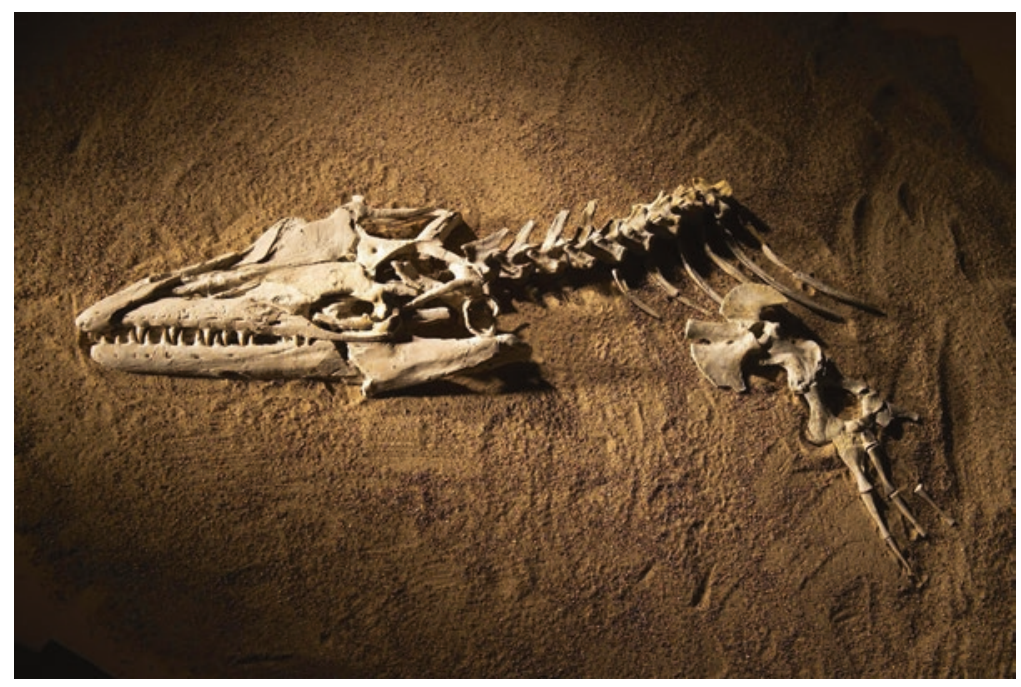

Fig. 4.3 The mosasaur Angolasaurus bocagei skull and anterior postcrania (Museum of Geology, Universidade Agostinho Neto). (Photo: Hillsman Jackson, Southern Methodist University) 


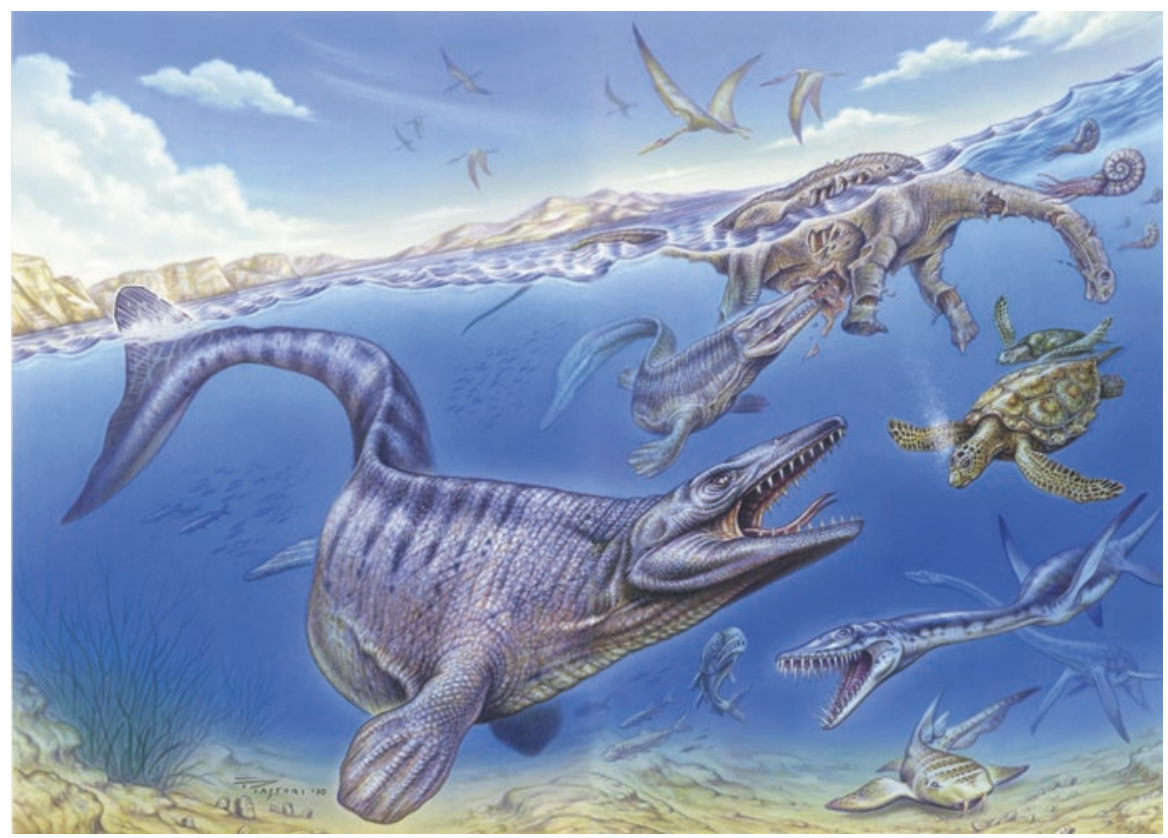

Fig. 4.4 Reconstruction of the fauna during the Late Cretaceous, based on the Coniacian fauna of Iembe. Illustration using acrylic painting with brush by Fabio Pastori

Elasmosauridae are also abundant at Bentiaba where two taxa are known: Aristonectinae indet. and Cardiocorax mukulu (Araújo et al. 2015a, b).

\section{The Paleogene - Mammals Take Over}

The Paleogene Period begins at the end of the Cretaceous (66 Ma) and lasted until the Neogene Period 23.03 Ma. The Paleogene is the interval of Earth's history in which mammals diversified and flourished after the K/Pg mass extinction, when most large reptiles, and belemnites and ammonites went extinct. There is a dearth of terrestrial vertebrates, especially mammals, from the Paleogene of Angola. During the global Paleocene-Eocene Thermal Maximum (PETM), 55.8 million years ago, there occurred a sudden change of the climate that marked the end of the Paleocene and the beginning of the Eocene, one of the most significant periods of climate change in the Cenozoic era (Zachos et al. 2005). The best known Paleogene geologic section in Angola is that of Lândana in Cabinda Province. A recent study of the Paleocene and Eocene biota and strata of Lândana indicated that the PETM is missing from that section, either because the event was too short to be recorded at the sampling interval used or that it falls within one of the several stratigraphic gaps documented in the Lândana section (Solé et al. 2018). 


\section{Protista and Invertebrates}

Among the protists, foraminifera stand out as the most important and well-known taxonomic group in the Angolan marine series of Paleogene age, due to their importance for biostratigraphic correlations in offshore oil drilling and their equivalence with landward outcrops. Important works include those of Rocha (1973) and Kender et al. (2008), which include many Eocene and Oligocene characteristic taxa such as: Cyclammina cf. compressa, Nonion centrosulcatum, Cassidulina subglobosa, Globigerina ampliapertura, Bolivina cf. pygmaea, Bulimina alsatica, B. kacksonensis and B. nkomi.

In the Paleogene of Angola, molluscs remain the most speciose clade of invertebrates, comprising at least three nautiloids, 14 bivalves, and 21 gastropods (see Supplementary Material). The bivalves are mainly known from the Eocene (Lutetian) Quimbriz Formation along the Luculo River (Tavares et al. 2007) and include Leda africae, Noetia veatchi, 'Cardium'luculensis, 'C.' sandigii, Crassatella schoonoverae, Lucina cf. landanensis, Macrocallista palmerae, Metis olssoni, Pitar quimbrizensis, P. quipayensis, Protonoetia nigeriensis, Raetomya schweinfurthi, Venericardia angolae, and V. heroyi (Tavares et al. 2007). The three nautiloids are Cimomia landanensis, Deltoidonautilus caheni, Hercoglossa diderrichi from the Danian of Cabinda Basin, Landana (Soares 1965), and the gastropods are also mainly known from the Eocene, Lutetian of Luculo River (Tavares et al. 2007): Ficula roscheni, Fulguroficus harrisi, Pleurotoma angolae, P. rebeccae, Polinices (Neverita) angolae, Ringicula hughesae, Sinum dusenberryi, Surcula cf. ingens, and Turricula (Knefastia) angolensis.

Other groups such as Anthozoa, Arthropoda and Echinodermata, exist but are low in numbers (Dartevelle 1953).

\section{Vertebrates}

Paleogene marine sediments have been studied mostly in the Benguela Basin and in Cabinda. Adnet et al. (2009) recognized a new species of Eocene lamniform shark, Xiphodolamia serrata, from Benguela. Sharks and bony fishes from Cabinda have been listed by Solé et al. (2018), and Taverne (2016) has provided new information about osteoglossid fishes from Lândana. The tetrapods from the Paleogene of Angola are mostly from the fossil sites of Lândana (Solé et al. 2018) and Malembo in Cabinda. The section begins with Lower Paleocene strata at Lândana. Reptiles comprise the dyrosaurid crocodylomorph Congosaurus bequaerti, and indeterminate crocodilians (Jouve and Schwarz 2004; Schwarz 2003; Schwarz et al. 2006), the turtles Taphrosphys congolensis, a toxochelyid, and Cabindachelys landanensis (Myers et al. 2017). Along the Chiloango River, Cabinda, a vertebra of the snake Palaeophis was reported by Antunes (1964).

The youngest portion of the Cabinda section is at Malembo Point, south of Lândana, which was originally considered Miocene. The Malembo mammal fauna is comparable to the Early Oligocene fauna of the Fayum, Egypt because of the 
presence of the embrithopod Arsinoitherium, hyracoids such as Geniohyus aff. Mirus and Bunohyrax aff. Fajumensis, the proboscidean cf. Phiomia or Hemimastodon, the sirenian Halitherium, and a reported anthropoid canine (Hooijer 1963; Pickford 1986; Jacobs et al. 2016). Recent findings by Projecto PaleoAngola in Malembo include a ptolemaiidan molar more similar to Kelba from the Miocene of Songhor, Kenya (19.5 Ma) than to Fayum Ptolemaia, and an isolated premolar tooth of a large primate comparable in size to that of a female gorilla, likely an undescribed taxon (Jacobs et al. 2016), and not representing any of the numerous Fayum primate taxa. In addition, Arsinoitherium is now known from the latest Oligocene of Kenya. The presence of a Kelba-like ptolemaiadan, a unique primate, and Arsinoitherium may indicate a latest Oligocene or even earliest Miocene age for Malembo Point. The assemblage certainly has differences from the Fatum fauna and may indicate the presence of a lowland West Africa faunal province near the Paleogene-Neogene boundary in age and distinct from other regions such as the East African Rift Valley or the Fayum.

\section{The Neogene - The Founding of Modern Biodiversity}

The Neogene began about $23 \mathrm{Ma}$ and extends until the Pleistocene (1.8 Ma). It is divided into Miocene (23 Ma to 5.3 Ma) and Pliocene (5.3 Ma to 2.6 Ma), from the oldest to the more recent. This period saw the expansion of the large mammals, and the appearance of hominids. In the Miocene the climate warms again and grasslands and savannas spread. In the Pliocene, the Earth had become similar to the one we know today.

\section{Protists and Invertebrates}

The Neogene foraminifera of the Angolan coastal basins, including those from the Miocene Quifandongo series of the Cuanza Basin, are known from a diversity of planktonic and benthic taxa widely used in oil industry offshore correlations or as palaeoenvironmental indicators. Rocha (1957), Graham et al. (1965), Mcmillan and Fourie (1999) and Kender et al. (2009), among others describe the essentials of these West African foraminiferal assemblages, which include planktonic taxa such as Globigerina praebulloides, Globigerinella obesa, Globigerinoides bisphericus, G. immaturus, G. trilobus, Globorotalia peripheroronda and Orbulina bilobata.

Invertebrates are surprisingly poorly known and comprise, at least, the nautiloid mollusc Aturia luculoensis, the decapod crustacean Callianassa floridana from the Miocene Burdigalian of Cabinda Basin (Newton 1917), several taxa of Miocene echinoid echinoderms such as Clypeaster borgesi, Echinolampas antunesi, Rotula deciesdigitata, Rotuloidea vieirai, Amphiope neuparthi, and Plagiobrissus sp. (Loriol 1905; Dartevelle 1953; Gonçalves 1971; Kroh 2010; Silva and Pereira 2014; Pereira and Stara 2018), and two species of anthozoan corals Flabellum extensum 
and Stylophora raristella (Chevalier 1970). Nevertheless, bivalve and gastropod molluscs are undoubtedly the most diverse and abundant invertebrate taxa of the marine Neogene of Luanda, Benguela and Namibe, with several rich fossil sites, some of them presently in course of study. The molluscan faunas of these coastal basin areas, including new species such as Pereiraea africana, Clavatula loandensis or Chlamys silvai Antunes (1964), were the focus of Douvillé (1933), Keller (1934), Dartevelle (1952, 1953), Dartevelle and Roger (1954), Soares (1961, 1962), Silva (1962), Silva and Soares (1962), Antunes (1964), and more recently Antunes (1984), Lozouet and Gourgues (1995), among others.

\section{Vertebrates}

Mammals are known from Benguela and the Cuanza provinces where Projecto PaleoAngola collected skulls of fossil baleen whales. An odontocete has also been found from Barra da Cuanza.

In Angola the most abundant group of Neogene vertebrates are the Elasmobranchii chondrichthyans (18 taxa; see Supplementary Material). The following taxa are from the Pliocene of Farol das Lagostas (Cuanza Basin): Aetobatus, Carcharhinus egertoni, Carcharhinus priscus, Carcharias taurus, Carcharocles megalodon, Carcharodon carcharias, Galeocerdo cuvier, Hemipristis serra, Isurus benedeni, Isurus oxyrinchus, Mitsukurina, Myliobatis, Negaprion brevirostris, Paragaleus, Pristis, Pteromylaeus bovina, Rhinoptera brasiliensis, and Sphyrna zygaena (Antunes 1964). Five bony fishes are known, the actinopterygians Cybium, Sparus, Sphyraena barracuda, Tachysurus, and Tetrodon.

\section{The Quaternary - The Dominance of Humans}

The Quaternary (2.6 Ma to present, including the Pleistocene and Holocene) is the third geological period of the Cenozoic era and the most recent in the geological time scale. This period is characterised by the return of glaciations at higher elevations and latitudes, the dominant role of the genus Homo in all terrestrial habitats and the extinction of much of the megafauna.

\section{Invertebrates}

In Angola, the Quaternary biodiversity is again marked by the high number of mollusc taxa (73 or more), of which 29 are bivalves such as Arcopsis afra, Barbatia complanata, Cardium indicum, Chama crenulata, Glycymeris concentrica, Lutraria senegalensis, Noetiella congoensis, Ungulina cuneata from the Middle Pleistocene of Pipas (Namibe Basin) and 44 gastropods mainly known from Namibe Basin, such as Cantharus viverratus, Columbella adansoni, Conus babaensis, Siphonaria 
capensis, and Terebra senegalensis (Miller and Carpenter 1956; Sessa et al. 2013). Other invertebrates such as corals, arthropods and echinoderms are known but reduced to a handful of known taxa, such as Cladangia carvalhoi from the Pleistocene of Salinas de Bero, Saco, Namibe (Wood 1973). In most situations they occur in a variety of raised-beach and lagoonal deposits related to coastal uplift and major sea-level changes (Carvalho 1961). The post-glacial Holocene is marked by the accretion of sand-spits and deltaic facies with rich coquinas, including the bivalve Senilia senilis as a typical species (Dinis et al. 2016). See Supplementary Material for the updated list.

\section{Vertebrates}

A remarkable fossilized jaw (dentary bone) of Blue Whale Balaenoptera musculus present in the Museu Nacional de História Natural in Luanda measuring nearly seven meters in length is not only the largest known fossilized bone but also one of the largest whales, thus animals, ever recorded. Large land mammals, including Bubalus, Syncerus cf. nanus Boddaert; Phacochoerus sp., Equus, Hippotigris cf. zebra have been reported from the site called Cemitério dos Ossos, north of Luanda (Antunes 1961).

The caves of Humpata, in Huíla Province, in southern Angola, are formed in Chela Dolomite that hosts fossiliferous caves and fissures (Amaral 1973; Antunes 1965; Arambourg and Mouta 1952; França 1964; Mouta 1950). Pickford et al. (1990, 1992, 1994) listed taxa of mammals from the Humpata Caves. These include the insectivore Crocidura, a Macroscelididae, the chiropteran Rhinolophus, Miniopterus, Nycteris, 19 genera of rodents (Uranomys, Acomys, Dasymys, Aethomys, Thallomys, Zelotomys, Mus, Pelomys, Malacomys, Praomys, Grammomys, Dendromus, Steatomys, Petromyscus, Tatera, Otomys, Cryptomys, Graphiurus, and Hystrix), the lagomorph Serengetilagus, Mustelidae, Viverridae, Canidae, and the Hyaenidae cf. Chasmoporthetes, the Hyracoidea Gigantohyrax and Procavia, Rhinocerotidae, Equidae, Suidae Metridiochoerus andrewsi and the Bovidae Hippotragini and Connochaetes.

The most thoroughly studied of the Humpata fossils are those of the extinct baboon. Cercopithecid primates from Humpata caves include Soromandrillus quadratirostris, cf. Theropithecus sp., and Cercopithecoides sp. (dated as ca. 2.03.0 Ma) (Minkoff 1972; Jablonski 1994; Jablonski and Frost 2010; Gilbert 2013).

Pleistocene deposits in Namibe provided remains of fossilized ostrich Struthio eggshells, artiodactyl bones and numerous human artifacts - including Acheulean hand axes (amygdaloid bifaces) suggesting the presence of early humans, such as Homo ergaster or $H$. erectus, whereas bones of early humans are not known in Angola. 


\section{Final Remarks on the Fossil Record and Paleobiodiversity}

Measuring paleobiodiversity is challenging due to the sparse and limited availability of data, compared with modern extant faunas. The paleobiodiversity of Angola is mostly known from Cretaceous and Cenozoic fossils that comprise $90 \%$ or more of all known fossil records of Angolan taxa (see Table 4.1 and Supplementary Material). The vast preponderance of the fossil taxa is marine which is consistent with the geological settings and paleogeography, related to the opening of the South Atlantic and repeated inundation of the Angolan continental margin.

For this study, we compiled a list of taxa using species, genus or the lowest known taxonomical clade reported in the scientific literature for Angola (see Supplementary Material). Of the resulting list of more than 1300 fossil taxa, many may require systematic revision and the final number will depend on the validity of the taxonomy.

By far the most speciose group are the molluscs (about $61 \%$ of taxa, more than half being Cretaceous ammonites) and Cretaceous foraminiferans (16\%), followed by vertebrates with about $15 \%$ of taxa. Chondrichthyes and mammals represent $6 \%$ and $5 \%$ of taxa, respectively.

About $10 \%$ of vertebrate taxa listed are unique or were first recognised in Angola, most of them receiving species names after localities in Angola or of geologists that worked in the country. According to current knowledge, at least 67 taxa (6.1\%) of invertebrates are endemic or were first mentioned from Angola.

\section{References}

Adnet S, Hosseinzadeh R, Antunes MT et al (2009) Review of the enigmatic Eocene shark genus Xiphodolamia (Chondrichthyes, Lamniformes) and description of a new species recovered from Angola, Iran and Jordan. J Afr Earth Sci 55(3-4):197-204

Amaral L (1973) Nota sobre o "karst" ou carso do Planalto do Humpata (Huila), no Sudoeste de Angola. Garcia de Orta 1:29-36

Anchieta J (1885) Traços geológicos da África Occidental Portuguesa. Tipografia Progresso, Benguela, $15 \mathrm{pp}$

Antunes MT (1961) A jazida de vertebrados fósseis do Farol das Lagostas: II Paleontologia. Boletim dos Serviços de Geologia e Minas de Angola 3:1-18

Antunes MT (1964) O Neocretácico e o Cenozóico do litoral de Angola. Junta de Investigações Ultramar, Lisboa, $255 \mathrm{pp}$

Antunes MT (1965) Sur la faune de vertébrés du Pléistocène de Leba, Humpata (Angola). Actes du Ve Congrès Panafricain de Préhistoire et de l'Étude du Quaternaire. Tenerife, 127-128

Antunes MT (1970) Paleontologia de Angola. In: Curso de Geologia do Ultramar. Junta de Investigações do Ultramar, Lisboa, pp 126-143

Antunes MT (1984) Étude d'une faune gastéropodes miocène récoltés par M. M Feio dans le Sud de l'Angola Comunicações dos Serviços Geológicos de Portugal 70(1):126-128

Antunes MT, Cappetta H (2002) Sélaciens du Crétacé (Albien-Maastrichtien) d'Angola. Palaeontographica, Abteilung A 264 (5-6):85-146

Antunes MT, Maisey JG, Marques MM, et al (1990) Triassic fishes from the Cassange depression (R.P. de Angola). Ciências da Terra (UNL), special number 1:1-64 
Arambourg C, Mouta F (1952) Les grottes et fentes à ossements du sud de l'Angola. Actes du IIème Congrès Panafricain de Préhistoire d'Alger 12:301-301

Araújo AG, Guimarães F (1992) Geologia de Angola, Notícia explicativa da Carta Geológica à escala 1: 1000 000. Serviço Geológico de Angola, Luanda, 140 pp

Araújo R, Polcyn MJ, Lindgren J et al (2015a) New aristonectine elasmosaurid plesiosaur specimens from the Early Maastrichtian of Angola and comments on paedomorphism in plesiosaurs. Neth J Geosci 94(1):93-108

Araújo R, Polcyn MJ, Schulp AS et al (2015b) A new elasmosaurid from the early Maastrichtian of Angola and the implications of girdle morphology on swimming style in plesiosaurs. Neth J Geosci 94(1):109-120

Archibald JD, Clemens WA, Padian K et al (2010) Cretaceous extinctions: multiple causes. Science 328(5981):973-973

Berry CT (1939) A summary of the fossil Crustacea of the Order Stomatopoda, and a description of a new species from Angola. Am Midl Nat 21(2):461-471

Blake DB, Breton G, Gofas S (1996) A new genus and species of Asteriidae (Asteroidea; Echinodermata) from the Upper Cretaceous (Coniacian) of Angola, Africa. Paläontol Z 70(1-2):181-187

Borges A (1946) A costa de Angola da Baía da Lucira à Foz do Bentiaba (entre Benguela e Mossâmedes). Boletim da Sociedade Geológica de Portugal 5(3):141-150

Boule M, Lemoine P, Thevenin A (1907) Paléontologie de Madagascar. III Céphalopodes crétacés des environs de Diègo-Suarez. Annales de Paléontologie 2:1-56

Brandão JM (2008) "Missão Geológica de Angola": contextos e emergência. Memórias e Notícias, new series 3:285-292

Brandão JM (2010) O "Museu de Geologia Colonial" das Comissões Geológicas de Portugal: contexto e memória. Revista Brasileira de História da Ciência 3(2):184-199

Buta-Neto A, Tavares TS, Quesne D et al (2006) Synthèse préliminaire des travaux menés sur le bassin de Benguela (Sud Angola): implications sédimentologiques et structurales. Áfr Geosci Rev 13(3):239-250

Callapez PM, Gomes CR, Serrano Pinto M et al (2011) O contributo do Museu e Laboratório Mineralógico e Geológico da Universidade de Coimbra para os estudos de Paleontologia Africana. In: Neves LF, Pereira AC, Gomes CR, Pereira LCG, Tavares AO (eds) Modelação de Sistemas Geológicos. Homenagem ao Professor Doutor Manuel Maria Godinho. Laboratório de Radioactividade Natural da Universidade de Coimbra, Coimbra, pp 159-174

Carvalho GS (1961) Geologia do deserto de Moçâmedes, (Angola): Uma contribuição para o conhecimento dos problemas da orla sedimentar de Mocâmedes. Memórias da Junta de Investigações do Ultramar 26:1-227

Ceraldi TS, Green D (2016) Evolution of the South Atlantic lacustrine deposits in response to Early Cretaceous rifting, subsidence and lake hydrology. In: Ceraldi S, Hodgkinson RA, Backe G (eds) Petroleum geoscience of the West Africa Margin. Geological Society, London, Special Publications, 438, doi: https://doi.org/10.1144/SP438.10

Chevalier JP (1970) Les Madreporaires du Neogene et du Quaternaire de l'Angola [Neogene and Quaternary corals from Angola]. Annalen Koninklijk Museum voor Midden-Afrika 8: Geologische Wetenschappen 68:13-33

Collignon M (1978) Ammonites du Crétacé Moyen-Supérieur de l'Angola. $2^{\circ}$ Centenário Academia das Ciências. Estudos de Geologia e Paleontologia e de Micologia, Academia das Ciências, Lisboa, pp 1-75

Cooper MR (1972) The Cretaceous stratigraphy of San Nicolau and Salinas, Angola. Ann S Af Mus 6(8):245-251

Cooper MR (1982) Lower Cretaceous (Middle Albian) ammonites from Dombe Grande, Angola. Ann S Af Mus 89:265-314

Cooper MR, Kennedy WJ (1979) Upper most Albian (Stoliczkaia dispar zone) ammonites from the Angolan littoral. Ann S Af Mus 77:175-308 
Crampton JS, Beu AG, Cooper RA et al (2003) Estimating the rock volume bias in paleobiodiversity studies. Science 301(5631):358-360

Dartevelle E (1952) Echinides fossiles du Congo et de l'Angola. Partie 1: Introduction historique et stratigraphique. Annales du Musée Royal du Congo Belge, série 8, Sciences Géologiques 12:1-70

Dartevelle E (1953) Echinides fossiles du Congo et de l'Angola. Partie 2: description systématique des échinides fossiles du Congo et de l'Angola. Annales du Muséum Royal du Congo Belge, série 8, Sciences Géologiques 13:1-240

Dartevelle E, Roger J (1954) Contribution à la connaissance de la faune du Miocène de l'Angola. Comunicações dos Serviços Gelógicos de Portugal 35:227-312

Dinis P, Huvi J, Cascalho J, Garzanti E, Vermeesch P, Callapez P (2016) Sand-spits systems from Benguela region (SW Angola). An analysis of sediment sources and dispersal from textural and compositional data. J Afr Stud 117:181-192

Douvillé H (1933) Le Tertiaire de Loanda. Boletim do Museo e Laboratorio Mineralógico e Geológico da Universidade de Lisboa, 1:63-118

Duarte LV, Callapez PM, Kalukembe A, et al (2014) Do Proterozoico da Serra da Leba (Planalto da Humpata) ao Cretácico da Bacia de Benguela (Angola). A geologia de lugares com elevado valor paisagístico. Comunicações Geológicas 101(Especial III):1255-1259

Ferré B, Granier B (2001) Albian roveacrinids from the southern Congo Basin off Angola. J S Am Earth Sci 14:219-235

Ferreira JM, Rocha AT (1957) Foraminíferos do Senoniano de Catumbela (Angola). Garcia de Orta 5(3):517-545

Ferreira OV (1957) Acerca de Parapirimela angolensis Van Straelen nas Camadas de Iela, Angola. Comunicações dos Serviços Geológicos de Portugal 38:465-468

França JC (1964) Nota preliminar sobre uma gruta pré-histórica do Planalto da Humpata (Angola). Junta de Investigações do Ultramar 2(50):59-67

Gilbert CC (2013) Cladistic analysis of extant and fossil African papionins using craniodental data. J Hum Evol 64(5):399-433

Gonçalves F (1971) Echinolampas antunesi, nov. sp. Cassidulidae, échinide nouveau du Miocène de la région de Luanda, Angola. Revista da Faculdade de Ciências, C - Ciências Naturais 16(2):307-310

Graham JJ, Klasz I, Rerat D (1965) Quelques importants foraminifères du Tertiaire du Gabon (Afrique Equatoriale). Revue de Micropalèontologie 8:71-84

Green PF, Machado V (2015) Pre-rift and synrift exhumation, post-rift subsidence and exhumation of the onshore Namible margin of Angola revealed from apatite fission track analysis. In: Sabato Ceraldi T, Hodgkinson RA, Backe G (eds) Petroleum geoscience of the West Africa Margin. Geological Society, London, Special Publications 438, pp 99-118

Greyling MR, Cooper MR (1995) Two new irregular echinoids from the Upper Cretaceous (midCampanian) of Angola. Durban Museum Novitates 20(1):63-71

Guiraud R, Maurin JC (1991) Le rifting en Afrique au Crétacé Inférieur: Synthèse structural, mise en évidence de deux phases dans la genèse des bassins, relations avec les ouvertures océaniques péri-africaines. Bulletin de la Société Géologique de France 165(5):811-823

Guiraud M, Buta-Neto A, Quesne D (2010) Segmentation and differential post-rift uplift at the Angola margin as recorded by the transform - rifted Benguela and oblique-to-orthogonal-rifted Kwanza basins. Mar Pet Geol 27:1040-1068

Haas O (1942) The vernay collection of cretaceous (Albian) ammonites from Angola. Bull Am Mus Nat Hist 81(1):1-224

Haas O (1943) Some abnormally coiled ammonites from the Upper Cretaceous of Angola. Am Mus Novit 1222:1-17

Haughton SH (1924) Notes sur quelques fossiles crétacés de l'Angola (Céphalopodes et Échinides). Comunicações dos Serviços Geológicos de Portugal 15:79-106 
Hooijer DA (1963) Miocene mammals of Congo. Annales du Museum Royal d'Afrique Centrale, Series 8 Sciences Géologiques 46:1-77

Howarth MK (1965) Cretaceous ammonites and nautiloids from Angola. Bull Br Mus Nat Hist Geol 10:335-412

Howarth MK (1966) A mid-Turonian ammonite fauna from the Moçâmedes desert, Angola. Garcia de Orta 14(2):217-228

Jablonski NG (1994) New fossil cercopithecid remains from the Humpata Plateau, southern Angola. Am J Phys Anthropol 94(4):435-464

Jablonski NG, Frost S (2010) Cercopithecoidea. In: Werdelin L, Sanders WJ (eds) Cenozoic Mammals of Africa. University of California Press, Berkeley, pp 393-428

Jackson JB, Johnson KG (2001) Measuring past biodiversity. Science 293(5539):2401-2404

Jacobs LL, Mateus O, Polcyn MJ et al (2006) The occurrence and geological setting of Cretaceous dinosaurs, mosasaurs, plesiosaurs, and turtles from Angola. J Paleontol Soc Korea 22:91-110

Jacobs LL, Mateus O, Polcyn MJ et al (2009) Cretaceous paleogeography, paleoclimatology, and amniote biogeography of the low and mid-latitude South Atlantic Ocean. Bull Geol Soc Fr 180(4):333-341

Jacobs LL, Polcyn MJ, Mateus O et al (2016) Post-Gondwana Africa and the vertebrate history of the Angolan Atlantic Coast. Mem Mus Vic 74:343-362

Jones TR (1862) A Monograph of the fossil Estheriae. Palaeontol Soc 14:1-134

Jouve S, Schwarz D (2004) Congosaurus bequaerti, a Paleocene dyrosaurid (Crocodyliformes; Mesoeucrocodylia) from Landana (Angola). Bulletin de l'Institut Royal des Sciences Naturelles de Belgique, Sciences de la Terre 74:129-146

Keller A (1934) Contribution a la géologie de l'Angola. Le Tertiaire de Luanda. Description des especes, Mollusque. Lamellibranches. Boletim do Museo e Lab. Mineral. e Geol. do Universidade de Lisboa, la Ser, 3, pp 219-250

Kender S., Kaminski MA, Jones, BW (2008) Oligocene deep-water agglutinated foraminifera from the Congo Fan, offshore Angola: Palaeoenvironments and assemblage distributions. In: Kaminski MA, Coccioni R (eds) Proceedings of the seventh international workshop on agglutinated foraminifera. Grzybowski Foundation Special Publication 13, London, pp 107-156

Kender S, Kaminski MA, Jones BW (2009) Early to middle Miocene foraminifera from the deepsea Congo Fan, offshore Angola. Micropaleontology 54(6):477-568

Kier PM, Lawson M (1978) Index of living and fossil echinoids, 1924-1970. Smithson Contrib Paleobiol 34:1-182

Kroh A (2010) Index of Living and Fossil Echinoids 1971-2008. Annalen des Naturhistorischen Museums in Wien 112:195-470

Lapão LGP, Pereira ES (1971) Notícia explicativa Carta Geológica de Angola, escala 1:100 000, folha $n^{\circ}$ 206, Egito Praia. Direcção Provincial dos Serviços de Geologia e Minas, Luanda, $42 \mathrm{pp}$

Lapão LGP, Simões MC (1972) Notícia Explicativa da Carta Geológica de Angola, escala 1:100 000, Folha ${ }^{\circ} 184$, Novo Redondo. Direcção Provincial dos Serviços de Geologia e Minas, Luanda, $54 \mathrm{pp}$

Leriche M (1932) Sur les premiers fossiles découverts au nord de l'Angola, dans le prolongement des couches du Lubilash et des couches du Lualaba. Association Française pour l'Avancement des Sciences, Compte Rendu 56éme session: 1-6

Loriol P (1888) Matériaux pour l'étude stratigraphique et paléontologique de la province d'Angola. Description des Echinides. Mémoires de la Société de Physique et d'histoire naturelle de Genève 30(2):97-114

Loriol P (1905) Notes pour servir à l'étude des échinodermes. Fasc. 2 (3). Georg Editeur, Bâle/ Genève, pp 119-146

Lozouet P, Gourgues D (1995) Senilia (Bivalvia: Arcidae) et Anazola (Gastropoda: Olividae) dans le Miocène d'Angola et de France, témoins d'une paléo-province Ouest-Africaine. Haliotis, 24, pp 101-108 
Marliére R (1950) Ostracodes and Phyllopodes au Système du Karroo au Congo Belge et les régions avoisinantes. Annales du Muséum Royal du Congo Belge, Sciences Géologiques, Série $8(6): 1-43$

Marzola M, Mateus O, Schulp A, et al (2014) Early Cretaceous tracks of a large mammaliamorph, a crocodylomorph, and dinosaurs from an Angolan diamond mine. J Vertebr Paleontol, Program and Abstracts, 181

Masse P, Laurent O (2016) Geological exploration of Angola from Sumbe to Namibe: a review at the frontier between Geology, natural resources and the history of Geology. C R Geosci 348(1):80-88

Mateus O, Jacobs LL, Polcyn MJ et al (2009) The oldest African eucryptodiran turtle from the Cretaceous of Angola. Acta Paleontol Pol 54:581-588

Mateus O, Jacobs LL, Schulp AS et al (2011) Angolatitan adamastor, a new sauropod dinosaur and the first record from Angola. Anais da Academia Brasileira de Ciências 83(1):221-233

Mateus O, Polcyn MJ, Jacobs LL, et al (2012) Cretaceous amniotes from Angola: dinosaurs, pterosaurs, mosasaurs, plesiosaurs, and turtles. V Jornadas Internacionales sobre Paleontología de Dinosaurios y su Entorno, Salas de los Infantes, Burgos, pp 75-105

Mateus O, Marzola M, Schulp AS et al (2017) Angolan ichnosite in a diamond mine shows the presence of a large terrestrial mammaliamorph, a crocodylomorph, and sauropod dinosaurs in the Early Cretaceous of Africa. Palaeogeogr Palaeoclimatol Palaeoecol 471:220-232

Mcmillan IK, Fourie A (1999) Kwanza Basin coastal stratigraphy with atlas of Albian to Holocene Foraminifera species. De Beers Marine (Pty) Limited, Luanda, 167 pp

Miller AK, Carpenter LB (1956) Cretaceous and Tertiary Nautiloids from Angola. Estudos, Ensaios e Documentos da Junta de Investigações do Ultramar 21:1-48

Minkoff EC (1972) A fossil baboon from Angola, with a note on Australopithecus. J Paleontol 46(6):836-844

Mouta F (1950) Sur la présence du Quaternaire ancien dans les hauts plateaux du Sud de l'Angola (Humpata, Leba). Compte Rendu sommaire des Scéances de la Société géologique de France 14:261-262

Murray AM (2000) The palaeozoic, mesozoic and early cenozoic fishes of Africa. Fish Fish 1(2):111-145

Myers TS, Polcyn MJ, Mateus O et al (2017) A new durophagous stem cheloniid turtle from the lower Paleocene of Cabinda, Angola. Pap Palaeontol 2017:1-16

Néraudeau D, Mathey B (2000) Biogeography and diversity of South Atlantic Cretaceous echinoids: implications for circulation patterns. Palaeogeogr Palaeoclimatol Palaeoecol 156(1-2):71-88

Neto MGM (1970) O sedimentar costeiro de Angola. Algumas notas sobre o estado actual do seu conhecimento. In: Curso de Geologia do Ultramar, vol 2. Publicações da Junta de Investigações do Ultramar, Lisboa, pp 193-232

Newton RB (1917) On some Cretaceous Brachiopoda and Mollusca from Angola, Portuguese West Africa. Earth and environmental science. Trans R Soc Edinb 51(3):561-580

Nunes AF (1991) A Investigação Geológico-Mineira em Angola. Ministérios dos Negócios Estrangeiros, Ministério das Finanças, Instituto para a Cooperação Económica, Lisboa, 387 pp

Pereira P, Stara P (2018) Redefinition of Amphiope neuparthi de Loriol, 1905 (Echinoidea, Astriclypeidae) from the early-middle Miocene of Angola. Comunicações Geológicas, 104(1): in press

Pérez-Díaz L, Eagles G (2017) South Atlantic paleobathymetry since early Cretaceous. Sci Rep 7:11819. https://doi.org/10.1038/s41598-017-11959-7

Pickford M (1986) Première découverte d'une faune mammalienne terrestre paléogène d'Afrique sub-saharienne. Comptes rendus de l'Académie des Sciences Paris Série II 19:1205-1210

Pickford M, Fernandez T, Aço S (1990) Nouvelles découvertes de remplissages de fissures à primates dans le 'Planalto da Humpata', Huilà, Sud de l'Angola. Comptes Rendus de l'Académie des Sciences Paris, Série II 310:843-848 
Pickford M, Mein P, Senut B (1992) Primate-bearing Plio-Pleistocene cave deposits of Humpata, southern Angola. Hum Evol 7:17-33

Pickford M, Mein P, Senut B (1994) Fossiliferous Neogene karst fillings in Angola, Botswana and Namibia. S Afr J Sci 90:227-230

Polcyn M, Jacobs L, Schulp A, et al (2007) Halisaurus (Squamata: Mosasauridae) from the Maastrichtian of Angola. J Vertebr Paleontol 27(Suppl. to 3):130A

Polcyn MJ, Jacobs LL, Schulp AS et al (2010) The North African Mosasaur Globidens phosphaticus from the Maastrichtian of Angola. Hist Biol 22(1-3):175-185

Polcyn MJ, Jacobs LL, Araújo R et al (2014) Physical drivers of mosasaur evolution. Palaeogeogr Palaeoclimatol Palaeoecol 400:17-27

Quirk DG, Hertle M, Jeppesen JW, et al (2013) Rifting, subsidence and continental break-up above a mantle plume in the central South Atlantic. In: Mohriak WU, Danforth A, Post PJ, et al (eds) Conjugate Divergent Margins. Geological Society, London, Special Publication, 369: 185-214

Rennie JVL (1929) Cretaceous fossils from Angola (Lamellibranchia and Gastropoda). Ann S Afr Mus 28:1-54

Rennie JVL (1945) Lamelibrânquios e gastrópodes do Cretácico Superior de Angola (vol. 1). Junta das Missões Geográficas e de Investigações Coloniais 1:1-141

Robles-Cruz SE, Escayola M, Jackson S et al (2012) U-Pb SHRIMP geochronology of zircon from the Catoca kimberlite, Angola: Implications for diamond exploration. Chem Geol 310311:137-147. https://doi.org/10.1016/j.chemgeo.2012.04.001

Rocha AT (1957) Contribuição para o estudo dos foraminíferos do Terciário de Luanda. Garcia de Orta 5(2):297-312

Rocha AT (1973) Contribution à l'étude des foraminifères paléogènes du bassin du Cuanza (Angola). Memórias e Trabalhos do Instituto de Investigação Científica de Angola 12:1-309

Rocha AT (1984) Notas micropaleontológicas sobre as formações sedimentares da orla mesocenozóica de Angola - V. O Maestrichtiano inferior da mancha de Cabeça da Baleia (a norte de Egito-Praia). Garcia de Orta, Série Geológica 7(1-2):97-108

Schlanger SO, Arthur MA, Jenkyns HC et al (1987) The Cenomanian-Turonian Oceanic Anoxic Event, I. Stratigraphy and distribution of organic carbon-rich beds and the marine $813 \mathrm{C}$ excursion. Geol Soc Lond, Spec Publ 26(1):371-399

Schulp AS, Polcyn MJ, Mateus O et al (2006) New mosasaur material from the Maastrichtian of Angola, with notes on the phylogeny, distribution and palaeoecology of the genus Prognathodon. On Maastricht Mosasaurs. Publicaties van het Natuurhistorisch Genootschap in Limburg 45(1):57-67

Schulp AS, Polcyn MJ, Mateus O et al (2008) A new species of Prognathodon (Squamata, Mosasauridae) from the Maastrichtian of Angola, and the affinities of the mosasaur genus Liodon. In: Proceedings of the Second Mosasaur Meeting, vol 3. Fort Hays State University Hays, Kansas, pp 1-12

Schulp AS, Polcyn MJ, Mateus O et al (2013) Two rare mosasaurs from the Maastrichtian of Angola and the Netherlands. Neth J Geosci 92(1):3-10

Schwarz D (2003) A procoelous crocodilian vertebra from the lower Tertiary of Central Africa (Cabinda enclave, Angola). Neues Jahrbuch für Geologie und Paläontologie, Monatshefte 2003:376-384

Schwarz D, Frey E, Martin T (2006) The postcranial skeleton of the Hyposaurinae (Dyrosauridae; Crocodyliformes). Palaeontology 49(4):695-718

Segundo J, Duarte LV, Callapez PM (2014) Lithostratigraphy of the Quissonde Formation marllimestone succession (Albian) of the Ponta do Jomba-Praia do Binge sector (Benguela Basin, Angola). Comunicações Geológicas 101(Especial III):567-571

Séranne M, Anka Z (2005) South Atlantic continental margins of Africa: a comparison of the tectonic vs climate interplay on the evolution of equatorial west Africa and SW Africa margins. J Afr Earth Sci 43(1-3):283-300 
Sessa JA, Callapez PM, Dinis PA et al (2013) Paleoenvironmental and paleobiogeographical implications of a Middle Pleistocene mollusc assemblage from the marine terraces of Baía das Pipas, southwest Angola. J Paleontol 87(6):1016-1079

Silva GH (1962) Fósseis do Miocénico de Luanda (Angola). Associação Portuguesa para o Progresso das Ciências. Actas do XXVI Congresso Luso-Espanhol (Porto, 22-26 June, 1962), sections II and IV, 3 pp

Silva R, Geirinhas F (2010) Colecções geológicas das antigas Províncias Ultramarinas Portuguesas arquivadas na Litoteca do LNEG. e-Terra 15(4):1-4

Silva R, Pereira P (2014) Redescoberta dos equinodermes fósseis das coleções históricas ultramarinas do LNEG. Comunicações Geológicas 101(Especial III):1379-1382

Silva GH, Soares AF (1962) Contribuição para o conhecimento da fauna miocénica de S. Pedro da Barra e do Farol das Lagostas (Luanda, Angola). Garcia de Orta 9:721-736

Soares AF (1961) Nouvelle espèce de Chlamys du Miocène de la région de Luanda (Angola). Memórias e Notícias 51:1-6

Soares AF (1962) Nota sobre alguns lamelibrânquios e gastrópodes do Miocénico de Luanda (Angola). Memórias e Notícias 53:31.35

Soares AF (1965) Contribuição para o estudo dos lamelibrânquios Cretácicos da região de Moçâmedes. Serviços de Geologia e Mina de Angola Boletim 11:137-168

Solé F, Noiret C, Desmares D et al (2018) Reassessment of historical sections from the Paleogene marine margin of the Congo Basin reveals an almost complete absence of Danian deposits. Geosci Front. https://doi.org/10.1016/j.gsf.2018.06.002

Spath LF (1922) On Cretaceous ammonites from Angola, collected by Prof. J.W. Gregory, D.Sc., F.R.S. Trans R Soc Edinb Earth Sci 53:91-160

Spath LF (1931) On cretaceous Ammonoidea from Angola, collected by Pr. J.W. Gregory. Trans Geol Soc Edinb. 53 (1):91-160

Spath LF (1953) The Upper Cretaceous cephalopod fauna of Grahamland. Sci Rep Falkland Islands Depend Surv 3:1-60

Strganac C, Salminen J, Jacobs LL et al (2014) Carbon isotope stratigraphy, magnetostratigraphy, and 40Ar/39Ar age of the Cretaceous South Atlantic coast, Namibe Basin, Angola. J Afr Earth Sci 99:452-462

Strganac C, Jacobs LL, Polcyn M et al (2015a) Stable oxygen isotope chemostratigraphy and paleotemperature regime of mosasaurs at Bentiaba, Angola. Neth J Geosci 94(1):137-143

Strganac C, Jacobs LL, Polcyn MJ et al (2015b) Geological setting and paleoecology of the Upper Cretaceous Bench 19 marine vertebrate bonebed at Bentiaba, Angola. Neth J Geosci 94(1):121-136

Tasch P (1979) Permian and Triassic Conchostraca from the Bowen Basin (with a note on a Carboniferous leaiid from the Drummond Basin), Queensland. Aust Bureau Mineral Resour Geolo Geophys Bull 185:33-44

Tasch P (1987) Fossil Conchostraca of the Southern Hemisphere and continental drift: Paleontology, biostratigraphy, and dispersal. Memoir of the Geological Society of America 165:1-290

Tavares T (2006) Ammonites et échinides de l'Albien du bassin de Benguela (Angola). Systématique, biostratigraphie, paléogéographie et paléoenvironnement. Unpublished $\mathrm{PhD}$ Thesis, Université de Bourgogne, Dijon, 389 pp

Tavares T, Meister C, Duarte-Morais ML et al (2007) Albian ammonites of the Benguela Basin (Angola): a biostratigraphic framework. S Afr J Geol 110(1):137-156

Taverne L (2016) New data on the osteoglossid fishes (Teleostei, Osteoglossiformes) from the marine Danian (Paleocene) of Landana (Cabinda Enclave, Angola). Geo-Eco-Trop 40(4):297-304

Teixeira C (1947) Contribuição para o conhecimento geológico do Karroo da África Portuguesa. I-Sobre a flora fóssil do Karroo da região de Téte. Anais da Junta de Investigações do Ultramar, Estudos de Geologia e Paleontologia 2(2):9-28

Teixeira C (1948a) Fósseis vegetais do Karroo de Angola. Boletim da Sociedade Geológica de Portugal 7(1-2):73-77 
Teixeira C (1948b) Vegetais fósseis do grés do Quilungo. Anais da Junta de Investigações Coloniais 2:85-92

Teixeira C (1958) Note paléontologique sur le Karroo de la Lunda, Angola. Boletim da Sociedade Geológica de Portugal 12(3):83-92

Teixeira C (1961) Paleontological notes on the Karroo of the Lunda (Angola). Garcia de Orta 9(2):307-311

Van Straelen V (1937) Parapirimela angolensis. Brachyure nouveau du Miocène de l'Angola. Bulletin du Musée Royal d'Histoire Naturelle de Belgique 8(5):1-4

Vasconcelos P (1951) Sur la découverte d'algues fossiles dans les terrains anciens de l'Angola. Int Geol Congr XVIIIth Sess 14:288-293

Walker RT, Telfer M, Kahle RL et al (2016) Rapid mantle-driven uplift along the Angolan margin in the late Quaternary. Nat Geosci 9(12):909-914. https://doi.org/10.1038/NGEO2835

Wood RC (1973) Fossil marine turtle remains from the Paleocene of the Congo. Annales du Musée Royal d'Afrique Centrale, Sciences Geologiques 75:1-28

Zachos JC, Röhl U, Schellenberg SA et al (2005) Rapid acidification of the ocean during the Paleocene-Eocene thermal maximum. Science 308(5728):1611-1615

Open Access This chapter is licensed under the terms of the Creative Commons Attribution 4.0 International License (http://creativecommons.org/licenses/by/4.0/), which permits use, sharing, adaptation, distribution and reproduction in any medium or format, as long as you give appropriate credit to the original author(s) and the source, provide a link to the Creative Commons licence and indicate if changes were made.

The images or other third party material in this chapter are included in the chapter's Creative Commons licence, unless indicated otherwise in a credit line to the material. If material is not included in the chapter's Creative Commons licence and your intended use is not permitted by statutory regulation or exceeds the permitted use, you will need to obtain permission directly from the copyright holder.

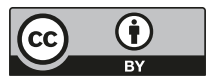

